Finch, J., Horan, C., and Reid, E. (2015) The performativity of sustainability: making a conduit a marketing device. Journal of Marketing Management, 31(1-2), pp. 167-192.

Copyright @ 2014 Westburn Publishers Ltd.

A copy can be downloaded for personal non-commercial research or study, without prior permission or charge

Content must not be changed in any way or reproduced in any format or medium without the formal permission of the copyright holder(s)

When referring to this work, full bibliographic details must be given

http://eprints.gla.ac.uk/99676

Deposited on: 19 June 2015

Enlighten - Research publications by members of the University of Glasgow http://eprints.gla.ac.uk 


\section{The performativity of sustainability: Making a conduit a marketing device}

John Finch, Adam Smith Business School, University of Glasgow, Gilbert Scott Building, West

Quadrangle, University Avenue, Glasgow, G12 8QQ, Scotland, UK, john.finch@glasgow.ac.uk

Conor Horan, School of Marketing, Dublin Institute of Technology, Aungier Street, Dublin 2, Ireland, conor.horan@dit.ie

Emma Reid, Department of Marketing, University of Strathclyde Business School, Stenhouse Building, 173 Cathedral Street, Glasgow G4 ORQ, Scotland, UK, e.a.reid@strath.ac.uk

Corresponding author: Professor John Finch, Adam Smith Business School, University of Glasgow, Gilbert Scott Building, West Quadrangle, University Avenue, Glasgow, G12 8QQ,

Scotland, UK, email john.finch@glasgow.ac.uk, telephone +44 1413302843 


\section{Abstract}

This paper examines how a conduit, as a 'working infrastructure' with material and social qualities, shapes and connects the business and practices of sustainable waste management. Conduits have had a prominent but passive role in explanations of food leftovers within households. We show that a conduit, as an assemblage of investments and practices among interested actors, requires and allows for the further economisation and calculation of waste management. Conduits shape business-to-business exchanges and relationships, deriving demand across domains of exchange and managing risks to the continuation of industrial processes. They resist singular stewardship, instead allowing multiple actors to recognise their interdependence and contest the development of facilities and services. Marketing communications form an important dimension of the conduit, albeit distributed across different parts of the conduit, in aligning actors' practices of sorting and 'moving things along' at and between locations.

Key words: Conduit, performativity, waste management, sorting, economizing

The paper's contribution is to demonstrate that:

(1) The sustainable management of food waste involves business-to-business marketing, especially in assessing how demand is derived across a succession of industrial processes and domains of exchange;

(2) Some significant practices in waste management processes are performative in respect of the material and social qualities of a conduit, for example in households' participation, and waste management companies' investments in processing facilities; and

(3) In combination, installing and using a conduit as a working infrastructure for sustainable waste management is an instance of performation, an expansive and long form of performativity. Contingently, the conduit guides the 'moving along' of food leftovers, allowing these to be calculated, economised and acquire the characteristics of commodity. 


\section{Introduction}

A fundamental assumption of business-to-business marketing is that business markets depend on derived demand, typically from consumer markets (Mattsson and Johanson, 2006, p. 264). This raises the question of how business marketers and their colleagues act to derive demand and connect markets, so forming a market or marketing system. This paper focuses on the multiple connections and interdependencies of a market and marketing system (Layton, 2011; Vargo, 2011), and considers how actors arrange a conduit by which markets and other domains of exchange may become connected and demand derived from one to another. Bowker and Star (1999, pp. 6-9) argue that the work of sorting things out involves developing 'working infrastructures', and in this paper we show that a conduit is one such instance. We understand that conduits have material and social qualities including, but not restricted to, being a theory of connecting markets, subject to multiple calculations and requiring multiple investments. We address the question of connection through presenting an exploratory study of sustainable waste management, concentrating on the ways in which waste management companies make significant investments in in anaerobic and other compositing facilities, which are of large-scale, are interdependent and have relatively long payback periods (Miller and O'Leary, 2007). We show that companies' capacities to make investments depend upon their market and marketing arrangements. These include the acquisition of supplies from markets upstream and of markets downstream having the capacity to purchase products, both requiring understandings of trends in the medium term among related markets. The investments are uncertain in the sense of companies not knowing the quantity of food leftovers to be available as feedstock, the plans of other waste management companies in installing facilities, and of the technical performance of facilities with different mixes of feedstock and of operating at different levels of capacity.

This paper's conceptual basis is in market studies and performativity, a critical insight of which is that markets enable exchanges, as an instance of acquiring agency, because they enable actors to economise; or to make calculations in advance of those exchanges and of making investments to support those exchanges (Callon, 1998a, 1998b; Callon and Muniesa, 2005; Pollock and Williams, 
2010; Araujo, Finch and Kjellberg, 2010). Performativity draws our attention to the ways in which theories, tools and models allow - without determining - actors to produce the kinds of data that those theories, models and tools presume or anticipate (MacKenzie and Millo, 2003; MacKenzie, 2006). The idea of performativity has been adopted within business and management studies, for instance with an interest in business processes and models (Doganova and Eyquem-Renault, 2009; Cabantous and Gond, 2011; Mason and Spring, 2011; D'Adderio and Pollock, 2014). These contributions highlight the importance of enrolling others within organisations and among suppliers and investors by sharing and circulating theories, tools, models and data (Beunza and Stark, 2004; Pollock and Williams, 2010). Given recent research, actors' deliberations in making investments are supported by their capacities to undertake calculations, which frequently are interdependent and can cluster (Richardson, 1962; Miller and O'Leary, 2007). By clusters of calculations, we mean that calculations are contingent, interdependent and undertaken among a coalition of actors, drawing in production facilities as well as market and marketing infrastructures; common in business markets. Together, market studies and performativity provide a novel perspective on the question of uncertainty through a concentration on the dual processes of framing and overflowing, which actors encounter in markets, especially when they contend with investments (Callon, 2010).

Our contribution is three-fold, in showing that: (1) The sustainable management of food waste involves business-to-business marketing in assessing how demand is derived across a succession of industrial processes and domains of exchange; (2) Some significant practices in waste management are performative in respect of the material and social qualities of a conduit, for example in households' participation and waste management companies' investments in processing facilities, and with public agencies providing reliable marketing knowledge to supplement that gathered in experience by waste management companies ; and (3) In combination, installing and using a conduit is an instance of performation, an expansive and long form of performativity. Contingently, the conduit guides the 'moving along' of food leftovers, allowing these contingently to be calculated, economised and acquire characteristics of a commodity. The case has currency in that surveys have traced the waste of food in households to consumers' purchasing practices and retailers' discounting practices (WRAP, 2013). There are 
controversies in waste management to include landfill taxes and environmental concerns with incineration plants (Doganova and Karnoe, forthcoming a, b). Furthermore, there is interest among policymakers in adopting anaerobic digestion as energy production from biomass, contributing to the ideal of a low carbon economy.

\section{Conduit: A review of the literature}

Hines (1993) argues that a conduit is a 'value pipeline' drawing together push and pull processes, or dual exchanges, between households and organisations. Reflecting on Bowker and Star's (1999) understanding of a conduit as 'working infrastructure', we can trace its role in allowing actors to sort things out again and again across an integrated system and in integrating a system. Crucial for examining a conduit is the distinction between its short and long or expansive forms. The distinction can be developed by applying performativity, which is that body of literature to consider the ways in which actors practice models, concepts and formula and so acquire data in order to make calculations and permit and motivate actions (MacKenzie, 2006; Callon, 2007).

\section{Conduits in short-form in waste management}

Research on waste and consumption has centred on households settings, assessing a conduit as a material entity, often in short-form and allied with household practices (Evans, 2012a; Cappellini and Parsons, 2013). By short-form, we mean that the subjects of research and researchers consider ways of moving things along, as waste, recycled as leftovers, hand-me-downs or donations, as connecting directly, straight-forwardly, passively and often visibly, to an end use. The critique of the understanding that consumption is a value sink implies that consuming extends beyond purchasing, with consuming (and exchanging) being far from neutral, scripted and passive from the perspective of acquiring, augmenting and managing the value of goods and services (Belk, 1987; Shove and Araujo, 2010). Gregson et al. (2007a, 2007b) capture the contingent quality of 'left-overs' in relation to material becoming waste. They write of 'surplus' if there is potential for the deployment of 
material in other (valuable and valued) uses or 'excess' if not, noting that usually surplus requires additional practices, processes and investment in salvage and recovery. For people with food leftovers, the conduit of the bin is close-at-hand, and this simplifies a process in short-form by which they can sort food leftovers, classify these as excess (Bulkeley and Gregson, 2009). By contrast, if people can imagine and make practical a potentially valuable other use, food leftovers can become surplus relative to a current use, requiring, for instance, sorting left-overs into conduits, which represent and ensure the 'moving along' to other uses and the recovery of value (Strasser, 1999; Evans, 2012a). An impetus to food's changeable classification is its material agency, which can be altered through the practices of preparation and storage, and investments in those practices, such as preserving, refrigerating and freezing (Pickering, 1995; Ingold, 2007). As Evans (2012a) shows, leftovers can be recycled as further meals often requiring an expansion of a conduit domestically to include additional practices, investments, and social and economic relations.

People can reclassify and redirect leftovers, taking on the quality of surplus to be moved along to a use valued by others (Appadurai, 1986; Kopytoff, 1986; Bulkeley, et al., 2007). Strasser (1999) provides historical accounts of peoples' skilful practices in managing and conserving food, and in finding uses often within households for what temporarily became surplus awaiting further use, rather than excess. Consuming generates surpluses, leftovers, offcuts, scraps, excess and mess (Law, 2004). Evans (2011) presents a critique of 'blame the consumer', of policies that aim to make food waste visible and associate it with consumers, for instance in their purchasing behaviours, as in WRAP's (2008) report, 'The Food We Waste'. This report promotes policies to change behaviours addressing what is alleged to be a poor match of food purchasing and consuming practices. A significant feature in Evans (2012a, 2012b) is how households cope with the operations at scale of food retailers, and of food production, distribution and packaging (Cochoy, 2008, 2010). People work skilfully, adaptively and imperfectly at domesticating products offered through large-scale agriculture, food processing and retailing. This personalising and 
singularising of food production, distribution and retailing at large scale poses problems for households in passing along food leftovers (Cappellini, 2009). Rather, food left-overs are often stored domestically drawing upon refrigeration or freezing, re-assembled and disguised as meals and acquiring greater personal and family significance, showing an embedding rather than alienating response to food leftovers (Cappellini and Parsons, 2013).

We should pay attention to food's material qualities as leftovers, of how these acquire agency and pose questions, an agenda, a narrowing and perhaps singularising of possibilities to people. Kopytoff (1986) and Callon et al. (2002) propose different explanations of singularising, of settling an entity into a particular set of qualities in anticipation of its use, such that it may be moved along as a gift or an exchange. Kopytoff investigates the overlapping practices of commoditising and singularising:

"Most of the time, when the commodity is effectively out of the commodity sphere, its status is inevitably ambiguous and open to the push and pull of events and desires, as it is shuffled about in the flux of social life. This is when it is exposed to the well-nigh-infinite attempts to singularise it" (Kopytoff, 1986, p. 83).

For Kopytoff, singularising is personal, removing an object from a market space and adapting and domesticating it. This raises the questions of how a singularised entity can be distant and distinct from commodity, and of how market actors contend with others' attempts at singularising an entity in social life and attempting to anticipate or even preempt these in a market sphere. Following Callon, et al. (2002), objects are in the throws of actors' attempts at commoditising and singularising, both of which can resolve ambiguity by preparing and sorting of an entity as singularised, personal and cultural, or commoditised and economic. It is not obvious that actors can move along (singular) food leftovers, sorted and classified to become (commodity) feedstock. Other conduits exist or can be formed, which assist in sorting, and formatting food leftovers, not so much as either surplus or 
excess, but as kinds of surplus, contingent upon a chosen conduit. We can expect that commoditising requires the work of sorting and categorising, drawing on tools, concepts and new practices that together become a new conduit.

Conduits in long-form, as investments

In extending the conduit into business markets, we find some comparable approaches proposed by researchers in the area of sustainable supply chains. Seuring and Müller (2008, p. 1700) emphasise the quality of 'managing material, information and capital flows' in sustainable development, and Ahi and Searcy (2013, p. 330) introduce 'co-ordination and voluntary integration of economics, environmental and social considerations'. Hines' (1993) 'value pipeline' illustrates how actors become connected, so facilitating their deriving of demand from other domains. By including producers and households, Hines reminds us systemically of the importance of demand's pull and the role of households in a value chain, influencing investments in a conduit, acknowledging the "importance of materials in whatever form flow efficiently and effectively to satisfy demand" (1993 p.15). Here we see a basis for understanding the conduit in its long form as a set of interrelated processing facilities, typically as long-lived assets and subject to investment.

Waste management draws the attention of companies, households and researchers to the material and social qualities of a conduit in coping with food and other leftovers, including economic and political interests at comparatively large scale additional to the agency organised in and immediately around households. By assessing leftovers from the perspective of waste management, the conduit is seen in long form by those actors for whom the provision and operation of an infrastructure is problematic. We do not conflate the scale of processing activities and facilities with the construct of levels (which we are not using). Scaling-up requires commercial and material practices such as investment appraisal, project management and operations governance, implicated in what we refer to 
as 'long-form'; an achievement contingent upon sorting, combining and processing materials (Bowker and Star, 1999, pp. 312-13; Latour, 2005, p. 185).

Marketisation, including of business-to-business exchanges, is of long-standing in the recovering or salvaging of surplus value at different stages in food production, including among households (Strasser, 1999). Marketisation also contrasts with recent studies of thrift and waste characteristic of some household consumption practices. Changes in legislation in the uses of landfill for waste and incentives to develop sources of renewable energy have led local authorities and waste management companies to develop market devices such as waste management contracts. By marketising, Çalişkan and Callon (2010, p. 3) refer to "the entirety of efforts aimed at describing, analysing and making intelligible the shape, constitution and dynamics of a market socio-technical arrangement", and draw out three dimensions: (1) the conception, production and circulation of goods and transfers of property rights; (2) comprising heterogeneous constituents; and (3) being a space of confrontation and power struggles, fuelled partly by multiple contradictory definitions and valuations. This last clause, multiple contradictory definitions and valuations, is also known as framing (Callon, 1998b). It qualifies marketed entities as performations because the frames are temporary resolutions in definition, valuation and exchange, impinging on ways of organising exchanges and organising entities to be exchanged (Kjellberg and Helgesson, 2006). Furthermore, Mol (2002), emphasises the multiple rather than plural (or infinite) versions of entities, drawing attention to the durable processes and techniques available in a market to help stabilise, cool-off and make tradable those entities. As Callon and Muniesa (2005) and MacKenzie (2009) argue, markets are devices for making (singular) things also the same (commodity) and considerable work is required in markets to achieve singularity and comparability. We expect marketing actors continually to be establishing ways of calculating and recalculating entities to become of equivalent value, and to be destabilising these by proposing other ways of calculating and introducing new products, services, images, and to undertake marketing campaigns to portray things as being distinct or singular (Callon, et al., 2002; Finch and Geiger, 2010, 2011). 
Marketising is significant because it opens processes of singularising to different ways of calculation (of engaging with the quality of commodity), and to the attempts among market professionals to detach entities from established uses, such as food leftovers as an excess or a surplus to be re-used within a household, and re-attach them elsewhere, such as to feedstock. Marketisation provides a basis to draw out the problems in contending with uncertainty of a number of organisations making interdependent investments in long-lived assets, which have multiple time frames among their heterogeneous components (Richardson, 1960; Miller and O'Leary, 2007; Callon, 2009). The uncertainty is encountered by a host of market actors, for instance in trying to assemble a conduit so that food leftovers can become a feedstock for different composting processes at large scale. When investments are more or less simultaneous and inter-dependent, policy and promises are significant ways of coordinating these (Pollock and Williams, 2010).

A conduit as well-used infrastructure implies a short and linear process, a stable sociotechnical assemblage of materials and social practices (Callon, 2007). For a view of conduit in short form to be feasible, we expect that it be held in place as various interests are enrolled in different ways, involving complementary investments and in habits and practices among its users. Commitments to investing and using an infrastructure are made with respect to different arguments, calculations, standards of evidence, and promises, considered over different durations (Pollock and Williams, 2010). Gregson et al. (2013) take the step of investigating the recycling of ships as an economic or economised activity within the industrial setting. They show the vulnerability of the process to changes in government policy, indicating that conduits and their political support are vital in holding recycling activities in place. Additionally, Miller and O'Leary (2007), examine the supporting role of broad-based techniques and principles in the case of technology road mapping for semiconductors. They assess the ways in which large companies and an industry association align investment decisions and support the development of markets, with an emphasis on the performativity of techniques of calculation. 
It is appropriate to consider conduits in long form when their performation is not yet settled, when businesses are considering investing in the infrastructure and users are considering adapting their practices so as to use one conduit ahead of others. We expect that the enrolments and calculations of different actors will become connected, exhibiting patterns of clusters in households, waste collection, waste management, waste processing and endof-waste commercialising. However, the question of scale has been addressed only briefly in research into waste as this has concentrated on the practices among households, domestically (Evans, 2012a). Assessments of how actors make translations, for instance between left-overs as excess and as surplus, as activities to be organised in close successions and at different scale, are under-researched, though feature in Doganova and Karnoe's (forthcoming, a, b) analyses of 'clean farms'. Assessments of a conduit, focusing on industrial use and business-to-business exchanges, combine calculation, modes of economising and means of enrolling peoples' practices and materials (Latour, 2005).

\section{Performativity and conduits}

We summarise this section's main points in Table 1 (below). It shows that a conduit is neither of short or long form per se, but is framed more or less expansively depending upon actors' use of it, and of their activities in seeking to extend that conduit. Performativity is an experiment 'in the wild' and 'of scale one', and applications of models are likely to be contested as others attempt performations of different models, of making visible and contesting the ways in which an activity is framed. Hence, performativity may be assessed as being more or less successful in its enactments and in enrolling others, ahead of being more or less accurate epistemologically (Callon, 2010). Perlocutionary performativity, or performation, extends the consequences of actors adopting a theory, model or concept beyond an illocutionary instance with an immediate, observed effect, to a long or extensive form. That long form brings into question the framing, often contested, of a domain of action, the joining together and contingency of different theories and tools, utterances and 
materials. In summary, and as we set out in Table 1 (below, towards the end of this section) performativity is consistent with research into conduits, when assessed beyond being an immediate route of disposal to consider a recovery of value through economised and industrial processes.

In considering conduits in long-form, for example, as waste management and treatment processes, actors can bring into their framing investments at large scale as well as exchanges that draw upon those investments. Performativity has the radical implication, captured in MacKenzie's (2006) title, of economics being 'an engine, not a camera'. This is discernible in Callon's (1998a, 1998b) argument that economics, economists and their theories and models are involved intimately in making economies and markets, primarily through the related activities of framing what counts within markets and coping with the overflowing consequences of framing. The idea of performativity has developed from Austin's (1962) explanation of speech acts; of how a person's utterance can bring into being a reality rather than that utterance describing more or less accurately a reality already in existence and available for observation, description and representation. Butler (1997) argues that Austin's explanation of speech acts is illocutionary, of very short form, and a special case of a more common (long form) perlocutionary performativity, in which speech, models, concepts, theories, and citations are combined over time in enactments. Butler prompts us to consider with perlocutionary performativity what is being held in place, what is doing the framing work, to allow a short form or illocutionary speech act to be possible. Primarily, Butler's $(1990,1997)$ concerns are cultural and linguistic, for instance, in gender identity and in the injurious potential of language. By extension, Pickering (1995) examines material performativity, captured, for instance, by scientists' instruments and experiments, in a 'mangle of practice', which again involves a long form of performativity, of the work of framing and of holding a practice in place.

MacKenzie and Millo (2003) and MacKenzie (2006) examine traders' uses of models as published by researchers in financial economics. Their interest is in the practical 
consequences of models, which may act as short-form utterances especially as facilitated by automated trading, but the long form is brought into focus when models mis-fire or become counter-performative (MacKenzie, 2006, 2009). Performativity captures the possibility that applications of a theory or model allow actors to frame and make reality 'more like' that represented in the model than would have been the case had the model remained confined to research papers. Callon (2007) develops this argument in assessing whether economists are developing models that enable people to become equipped, perform calculations, and acquire agency by being more like homo-economicus as assumed in some economic models. By counter-performativity, MacKenzie means the making of a reality in using a model, which is notably at variance to that anticipated in a particular model, of a model not working. For Butler (2010) and Callon (2007, 2010), counter-performativity, or 'mis-firing', is to be expected. Framings, such as economic or financial models, necessarily create overflows, which may be uncertain or volatile in their effects again encouraging us to consider a long form of performativity (of perlocution or performation). As we summarize in Table 1 (below) Perlocution and performation take the emphasis away from one particular theory being performed, or mis-firing, which is a development of the work by MacKenzie and Millo (2003) on the options pricing pricing model, and of Cabantous and Gond (2011) principal-agency theory. Rather, it places an emphasis on the multiple theories, models, calculus, apparatus and other means of formatting, extending to how these are held in place over time, allowing coalitions to acquire agency in recognition of uncertainty. 
Table 1, Conduits considered in short and long forms

\begin{tabular}{|c|c|c|}
\hline Generic qualities & Short form & Long form \\
\hline Published examples & $\begin{array}{l}\text { Illocutionary (Butler, 2010). } \\
\text { Food waste studies in } \\
\text { consumer behaviour, conduits } \\
\text { considered from within } \\
\text { households assist in a sorting } \\
\text { of leftovers into surplus or } \\
\text { excess. Passive, installed, } \\
\text { help households cope. }\end{array}$ & $\begin{array}{l}\text { Perlocutionary (Butler, 2010). } \\
\text { Few studies, one for ship } \\
\text { recycling (Gregson, et al., } \\
\text { 2013), carbon trading (Callon, } \\
\text { 2009; MacKenzie, 2009). } \\
\text { Conduit not in place, but } \\
\text { investments under } \\
\text { consideration. Questions } \\
\text { concern process, throughput, } \\
\text { scale. Active, not yet installed, } \\
\text { calculations to establish case } \\
\text { for installing, often distributed } \\
\text { among many actors. }\end{array}$ \\
\hline Cognitive, making calculations & $\begin{array}{l}\text { Deciding how to move things } \\
\text { along, or making the case for } \\
\text { storing things and postponing } \\
\text { the decision. }\end{array}$ & $\begin{array}{l}\text { Investment decision-making, } \\
\text { but likely to be highly } \\
\text { contingent on others' } \\
\text { investments, policy and } \\
\text { expected behaviours (Miller } \\
\text { and O'Leary, 2007). } \\
\text { Contending with high degrees } \\
\text { of uncertainty with fragmented, } \\
\text { overlapping and distinct data. }\end{array}$ \\
\hline Social, cultural, policy & $\begin{array}{l}\text { Contending with retailing } \\
\text { practices, worrying about } \\
\text { waste, singularizing to specific } \\
\text { domestic uses, possibility of } \\
\text { sacrifice, leftovers meals. } \\
\text { Affective within households, } \\
\text { friendships and families. }\end{array}$ & $\begin{array}{l}\text { Engagement with a number of } \\
\text { related environmental values } \\
\text { and policies, some tied in with } \\
\text { economic incentives, eg } \\
\text { carbon limits, landfill taxes. }\end{array}$ \\
\hline Material & $\begin{array}{l}\text { Installed infrastructures, some } \\
\text { domestic, refrigerators and } \\
\text { freezers, some close to hand, } \\
\text { waste collection and recycling, } \\
\text { second hand shops. Food } \\
\text { leftovers have unique material } \\
\text { agency }\end{array}$ & $\begin{array}{l}\text { Connecting markets, plants } \\
\text { and processes by a conduit, } \\
\text { not yet fully installed. Adapting } \\
\text { plant to the agency (bio- } \\
\text { chemical change) of materials } \\
\text { to be organized and } \\
\text { processed. Greater variance in } \\
\text { dimensions of material agency } \\
\text { to those considered in settled, } \\
\text { short form. }\end{array}$ \\
\hline Framing & $\begin{array}{l}\text { Defined, as conduit combines } \\
\text { cognitive/calculating, social } \\
\text { and material qualities as } \\
\text { above, helps frame decision- } \\
\text { making, and can be passive } \\
\text { once installed. Accumulations } \\
\text { of many small-scale spillovers } \\
\text { - mis-sorting, mis-collecting } \\
\text { (Callon, 1998b). }\end{array}$ & $\begin{array}{l}\text { Multiple, investments are being } \\
\text { evaluated, in recognition of } \\
\text { these being contingent on } \\
\text { others' plans. Framed by a } \\
\text { combination of policy } \\
\text { commitments, others' } \\
\text { investment plans in installing } \\
\text { capacity, plans to establish } \\
\text { conduits, and trials of } \\
\text { behaviour in using conduits. } \\
\text { Spillovers unclear as framing }\end{array}$ \\
\hline
\end{tabular}




\begin{tabular}{|c|c|c|}
\hline Generic qualities & Short form & Long form \\
\hline & & ambiguous (Callon, 2007). \\
\hline Performative & $\begin{array}{l}\text { Creates possibilities, changes } \\
\text { incentives, alters the balances } \\
\text { of commodity and singularity, } \\
\text { surplus and excess. } \\
\text { Establishes conduits without } \\
\text { determining the level of use. }\end{array}$ & $\begin{array}{l}\text { Multiple performations, } \\
\text { distinguished by scale, time } \\
\text { frame and coinciding or } \\
\text { overlapping policy objectives. }\end{array}$ \\
\hline
\end{tabular}

\section{Methodology and case background}

Research design

Methodologically, we focus on how actors move materials along within domains of exchange; undertake mediations between domains of exchange; and install conduits for sorting, exchanging and processing materials as they move materials along (Czarniawska, 2004; Latour, 1987). This paper reports on an exploratory study, seeking to develop a theory-based explanation in an under-researched setting, clarifying a unit of analysis by means of a single case study salient to a unit of analysis, and establishing bounds and limits to findings and conclusions based on that case (Barratt et al., 2011, p. 330). The unit of analysis establishes salience of the study with a theoretical or conceptual approach, and an expectation that further research can develop the exploratory study's contribution (Pan and Tan, 2011). 
Primarily, we drew upon data, documents and reports in the public domain, allowing us to follow and observe that which circulates and contributes to the performativity of exchanges and conduits in sustainable waste management (Latour, 2005). Waste management requires confidentiality among its companies and local authorities as they are involved in public sector procurement, competitive relationships in bidding and tendering for waste management contracts, and investing in processing facilities. At the same time, a number of reports, documents and more recently data sets are reported publicly through the government-supported agencies of the Waste and Resources Action Programme (WRAP), Zero Waste Scotland (ZWS) and the Scottish Environmental Protection Agency (SEPA). These include surveys of waste collection, the results of waste collection experiments, gate fee reports, newsletters, and documents published in connection with the planning process for new waste management facilities. We undertook six face-to-face interviews over March 2012 to April 2014, with durations of one hour to 90 minutes, recorded by hand-written notes. The purpose of the interviews was to establish the context of sustainable waste management and gain an insight into the technical capacities of anaerobic digestion (AD) and in-vessel composting (IVC), which are techniques of composting at large scale, deprived of oxygen, and allowing oxygen, respectively (DEFRA, 2011, 2012). We identified interviewees in different roles with one waste management company, including two business unit managers, an operations manager, a senior engineer, a business development manager and a sales manager. We participated in four policy workshops in May 2012, November 2012, November 2013 and February 2014, three of which were of three hours and one all day, supported by gathering workshop materials and making handwritten notes. Finally, we visited a trial AD plant in order to understand its technical process.

\section{Case background}

The case features an investment in an AD facility in central Scotland, as part of a waste management process. AD plants at larger-scale are being established in the UK, with 
typical capacities for biomass/organic feedstocks of between 30,000 and 80,000 tonnes annually. DEFRA (2012 p.5) reports 214 facilities in the UK, with combined processing capacity of over 5 million tonnes annually. The plants' operators typically require a combination of marketing initiatives, of earning gate fees by offering waste management services and offering energy, as heat or electricity or as biogas, augmented by different governmental incentives in the generation of power or heat from renewable sources. 146 of the facilities that DEFRA reports are long-established in the waste water and sewerage treatment sector, with one of these supplying gas directly into the national gas grid. DEFRA (2012 p.8) categorises 44 waste-led facilities in the UK, with a processing capacity of 3.7 million tonnes annually, potentially generating 54 mega-watts of power. AD is of interest to local authorities in that they manage waste that would otherwise be treated through landfill or incineration.

A recent licensing application for an AD plant - a little larger than the average reported by DEFRA (2012) - shows how they acquire feedstocks (SEPA 2010). The application was submitted by Zebec Biogas Limited for a facility with a capacity to process up to 75,000 tonnes per annum of organic feedstock. The feedstocks included 37,000 tonnes of segregated food waste (municipal food waste, commercial and other organisational food waste, including Category 3 animal by-products - as categorised under the EU's 2011 animal by-products regulations), 20,000 tonnes of agricultural slurries, and the remainder to include other sludges and organics, including waste, glycerols and biomass crops. Industrial sludges include waste components, for instance recovered by Dissolved Air Flotation processes used in treating effluents in water as part of meat, poultry and fish processing, can have higher calorific values especially if fats are included. Dissolved Air Flotation is another part of the technical assemblage by which feedstocks can be derived in food processing sectors and made available for anaerobic digestion, although some can also be used in animal feed. Crude glycerols are a co-product of biodiesel production (Miller-Klein Associates, 2006). To put this in context, SEPA (2014) report that in 2012 The City of Edinburgh composted 27,303 tonnes of animal and mixed food waste vegetal waste, 
both as household waste arisings, though this predates city-wide collections of separated food waste. The facility has two anaerobic digesters of $3,500 \mathrm{~m}^{3}$, a 40 -day process of fermentation to digest the feedstock materials, and powers two 1,000-kilowatt electrical engines. The maximum predicted output of the plant is biogas production of between 1,150 and $1,200 \mathrm{~m}^{3} / \mathrm{hr}$, with capacity to produce 15,500 tonnes of fibre fraction and 50,000 tonnes of liquid fraction (both of which are digestate, which can qualify for use as fertiliser). PAS110 provides a quality standard allowing both 'end of waste' status to be conferred upon the digestate and allowing this to be sold (BSI, 2010).

The operators of $A D$ facilities need to return an acceptable margin by offering waste management services for local authorities and for business and other organizational customers. Waste management companies operate in a number of markets, some established, in acquiring feedstock, offering waste management services, and selling outputs as power and possibly heat and digestate, all of which provide a practical version of the idea of sustainability and of qualifying some processed materials as no-longer being waste (from excess to surplus). Activities in acquiring feedstock are only occasionally aligned with investments in installing a facility, of contracts matching the expected lifespan of the asset, so the AD facility's operator encounters uncertainty (the business unit manager explained this in terms of exposure to risk in covering a facility's pay-back). The involvement of households as users of the conduit, connecting food leftovers with $A D$, is represented in a commercial contract between local authorities and companies offering waste management services.

\section{Findings}

In order to assess how the conduit provides a working infrastructure for a market system, we identify three domains of exchange, which are at the interstices of the conduit, where social and economic practices of exchange connect phases of processing activity and allow exchanges as actors move things along. We compare the three domains of exchange and assess their 
effectiveness in allowing actors to make calculations, especially in support of investments in processing equipment and in extending and developing the conduit.

\section{Domains of exchange}

We use 'domains of exchange' to capture: (1) The exchanges between households and local authorities; in addition to (2) Those between local authorities and waste management companies; and (3) Between waste management companies and wholesale buyers of gas and electricity. Together, these capture a market and marketing system, but the first of these domains is not organised as a market. In Table 2 (below) we organise our understanding of the three domains of exchange by considering each domain's participants, the means by which participants become equipped and formatted to participate, the investments made in those domains, and an understanding of what is being exchanged. In describing and assessing categories empirically, the themes are informed by Section 2 (above). 
Table 2, Findings across the domains of exchange

\begin{tabular}{|c|c|c|c|c|}
\hline & Participants & $\begin{array}{l}\text { Formatted and } \\
\text { equipped }\end{array}$ & $\begin{array}{l}\text { Investments in } \\
\text { markets \& other } \\
\text { domains of } \\
\text { exchange }\end{array}$ & $\begin{array}{l}\text { What is } \\
\text { exchanged? }\end{array}$ \\
\hline Domain 1 & $\begin{array}{l}\text { Households and } \\
\text { local authorities } \\
\text { Friends, families, } \\
\text { charities, retailers }\end{array}$ & $\begin{array}{l}\text { Sorting } \\
\text { categories, as } \\
\text { publicised } \\
\text { Techniques and } \\
\text { technologies of } \\
\text { postponement } \\
\text { Caddies, caddie } \\
\text { liners and } \\
\text { kerbside } \\
\text { collections }\end{array}$ & $\begin{array}{l}\text { Sorting, setting- } \\
\text { out and collecting } \\
\text { food left-overs } \\
\text { Food collection } \\
\text { trials and } \\
\text { experiments, } \\
\text { often subsidised } \\
\text { Waste (Scotland) } \\
\text { Regualtions } 2012\end{array}$ & $\begin{array}{l}\text { Food leftovers, } \\
\text { separated (not } \\
\text { commingled), set } \\
\text { out and collected } \\
\text { according to a } \\
\text { published } \\
\text { schedule. }\end{array}$ \\
\hline Domain 2 & $\begin{array}{l}\text { Local authorities, } \\
\text { waste } \\
\text { management } \\
\text { companies } \\
\text { (technologies } \\
\text { including landfill, } \\
\text { incineration, AD \& } \\
\text { IVC), and } \\
\text { collection } \\
\text { subcontractors }\end{array}$ & $\begin{array}{l}\text { Pre-qualification, } \\
\text { tendering and } \\
\text { contracting } \\
\text { Knowledge of } \\
\text { prevailing gate } \\
\text { fees } \\
\text { Access to a } \\
\text { waste processing } \\
\text { facility } \\
\text { Market } \\
\text { intelligence } \\
\text { Participating in } \\
\text { sorting and } \\
\text { collection trial or } \\
\text { experiment } \\
\text { Maps of } \\
\text { catchment areas }\end{array}$ & $\begin{array}{l}\text { Measurement by } \\
\text { weight across } \\
\text { sorted categories } \\
\text { Landfill tax }\end{array}$ & $\begin{array}{l}\text { Packages of } \\
\text { sorted and } \\
\text { collected food } \\
\text { leftovers for } \\
\text { contracted } \\
\text { periods, typically } \\
\text { of two years } \\
\text { Gate fees }\end{array}$ \\
\hline Domain 3 & $\begin{array}{l}\text { Multiple suppliers } \\
\text { of food leftovers } \\
\& \text { other organic } \\
\text { biomass } \\
\text { Partners in the } \\
\text { construction and } \\
\text { operation of } \\
\text { processing } \\
\text { facilities }\end{array}$ & $\begin{array}{l}\text { Processing } \\
\text { facilities } \\
\text { Calorific values of } \\
\text { feedstock } \\
\text { Qualities of } \\
\text { feedstock and } \\
\text { interactions in } \\
\text { process } \\
\text { Secondary } \\
\text { processes (eg, } \\
\text { gas scrubbing) }\end{array}$ & $\begin{array}{l}\text { Contracts for } \\
\text { acquiring } \\
\text { feedstock } \\
\text { Pay-back } \\
\text { conditions on } \\
\text { facilities } \\
\text { Legislation on } \\
\text { processing } \\
\text { animal by- } \\
\text { products } \\
\text { Subsidies in } \\
\text { exchanging } \\
\text { biofuel (Feed-in } \\
\text { Tariffs, } \\
\text { Renewable Heat } \\
\text { Incentives) }\end{array}$ & $\begin{array}{l}\text { Heat, electricity or } \\
\text { gas } \\
\text { Fertiliser (solid or } \\
\text { liquid) subject to } \\
\text { PAS110 standard } \\
\text { End of waste } \\
\text { status } \\
\text { Carbon saving } \\
\text { Risk, technical } \\
\text { and commercial }\end{array}$ \\
\hline
\end{tabular}


The scope of participants in moving along food leftovers in the first domain of exchange is well established in a series of reports by WRAP $(2008,2009,2010,2013)$ and Zero Waste Scotland $(2010,2014)$. These show the extent of food waste in the UK and report on trials in the collection of food leftovers by local authorities. Households are our focus, though we realise that people also move food leftovers along in a number of locations, including at work and when eating out. A notable difference between WRAP's $(2008,2013)$ reports is a change in emphasis from associating the question of wasting food with households, to include retailers' practices in packaging and sales promotion. WRAP's (2013, p. 23) report is of interest as it introduces a threeway categorisation of food waste as: unavoidable (tea bags, vegetable peelings), possibly avoidable (potato skins) and avoidable (food that has passed its sell-by date). The categorisation has important consequences by communicating a sorting process, equipping households in their sorting and categorising through marketing communication. Households are equipped with other storage and processing technologies that allow for a postponement of sorting, especially freezers. Some local authorities equip households with caddies and liners as additional ways of storing food leftovers, but these are already committing food leftovers to being moved along in waste management. Caddies are accompanied by kerbside collection schedules, the regularity of which can reinforce practices in the use of caddies, addressing concerns as to the deterioration of food leftovers as stored and awaiting collection. The main investments in this domain are made by local authorities in supplying caddies and offering a regular kerbside collection service. In addition, WRAP and Zero Waste Scotland (eg, Zero Waste Scotland, 2012) have offered subsidies aimed at supporting local authorities as they introduce collection services and have also funded collection trials. Finally, in the case of Scotland, the Waste (Scotland) Regulations (2012) specifies a timetable by which different organisation must sort and manage separate food waste, beginning with large organisations in 2012, small businesses in 2014 and households in 2016. To summarise, the exchange is of food leftovers, sorted and presented separately, for regular kerbside collection. The difficulty for the local authority is ensuring that households participate and undertake their sorting work effectively. 
The second domain is a business-to-business market in which local authorities and waste management companies participate. Local authorities collect household waste and can offer collection services alongside waste management companies to businesses and organisations. Waste management companies pre-qualify and tender for contracts to manage household waste as collected by local authorities, with contracts typically extending over one or two years. The market is thin in the sense of there being few participants and infrequent periods of contracting for relatively large contracts. Besides food waste, there is a wide range of waste categories that local authorities collect and tender for its management, with the array of categories defined and authorised by the Scottish Environmental Protection Agency (SEPA). In order to participate, waste management companies need to pre-qualify and then be awarded waste management contracts, requiring that they are equipped and formatted with a processing technology. AD is one technology, with differences in plant design requiring different mixes of feedstock (SEPA, 2010), and In-vessel Composting (IVC) is another. Some waste management companies operate combined facilities. Operationally, IVC can process co-mingled waste to include food left overs and garden waste but with greater restrictions on animal byproducts whereas AD can process food waste including Category C animal byproducts but cannot process woody garden waste. IVC produces compost, which can be sold subject to it satisfying the PAS100 standard (BSI, 2011). AD produces biogas, which can be used to generate electricity or processed further as methane alongside fertiliser, subject to it meeting PAS110 standard (BSI, 2010). Co-mingled waste collections are driven by garden waste, which imposes seasonality on waste management (Zero Waste Scotland, 2011, p. 38). Waste management companies develop notional catchment areas for their facilities, combining a number of local authorities and determined by relative transportation costs.

In addition, WRAP (eg, 2014) publishes a regular survey of gate fees across the UK charged by types of waste management facility, with some commentary on trends extending 12 months into the future. The main investment in the market is a publication of reports into volumes of waste, reported in different categories. SEPA $(2011,2014)$ undertakes this work in Scotland and has 
invested significantly in this service in recognition of the Waste (Scotland) Regulations (2012). Despite its relatively 'thin' character, the business-to-business market on managing domestic waste is well ordered, with an exchange of waste management services contracted typically for one or two years, paid for in gate fees by weight. By offering AD and IVC, waste management companies offer local authorities a way of avoiding land fill taxes, currently of $£ 80$ per tonne.

The third domain of exchange involves waste management companies and in the case of an AD plant users of electricity, methane and fertiliser (as the solid and liquid fraction produced alongside biogas). A concern in this domain is in making the AD facility work efficiently. The market becomes diffuse because waste management companies operating AD plants work with different technical specifications, many requiring a mix of feedstock (SEPA, 2010). Waste management companies offer services to companies and organisations in collecting separated food waste and other feedstock. Other biomass feedstock is available, but an array of established uses already exists. Food processing companies can offer wastes, including fats recovered through waste water treatment, for example using Dissolved Air Flotation equipment ${ }^{1}$. Biodiesel production produces glycerine as a byproduct (Miller-Klein Associates, 2006). Farms can spread slurry directly as a fertiliser, except in areas designated as sensitive to nitrogen and can grow crops suitable for processing as biomass. In operating an AD facility, waste management companies equip themselves with contracts for acquiring a range of feedstock, to fill gaps between capacity and feedstock from local authorities, manage the risks of being dependent on a single source, and enhance the technical efficiency of the AD facility. An important quality of feedstock is its calorific value. Following Andersons Centre (2010), these vary from the low levels in (partly digested) farm animal slurries, through biomass crops, domestic food waste, waste from food processing (which are higher in fat content), and glycerine. The latter tends also to cause foaming, which inhibits technical efficiency in AD processing. The most important investment this domain of exchange is in the feed-in tariffs offered by the UK government for producing gas and electricity from low carbon feedstock (DECC, 2009). The exchanges in this domain are diverse and regulated. The

\footnotetext{
${ }^{1}$ For example, a Nestle plant attracted publicity by ceasing to send its waste to landfill, having previously sent 12.5 tonnes per month to landfill (http://www.nestle.co.uk/media/pressreleases/Pages/NestleZerosInOWastelnGirvan.aspx).
} 
operators of the national grids for gas and electricity draw on different power sources to match predictable fluctuations in demand. AD plants have some potential to store biogas, prior to its conversion as 'scrubbed' methane to be fed in to the gas grid (DECC, 2011), or converted into electricity, but the production of biogas is subject to a forty-day lead time, and as two interviewees explained (one of the business unit managers and the senior engineer), the output varies with respect to the mix of feedstock and the efficiency of the AD process.

In summary, we present a market system organised into distinct domains of exchange. Three features are important: (1) Actors require different levels of visibility and understanding across the domains as they move food leftovers along; (2) The exchanges have multiple qualities, for instance in offering power and a contribution to low carbon targets, or offering waste management and the avoidance of landfill, such that demand is not derived in an overarching direction; and (3) Public and private sector organisations work alongside one another in multiple ways, including in undertaking exchanges, but also in investing in the market system, for instance with policies, standards, subsidies, operating permissions, trials, experiments and audited published data.

\section{Calculations}

Market studies researchers have argued that markets are devices in the sense of offering three interrelated services to its participants (Callon and Muniesa, 2005; Kjelberg and Helgesson, 2006): (1) A framing around a set of practices, artefacts, tools and objects, and making visible some of the spillovers of entities outwith that framing; (2) Making stable a set or array of products, goods and services to be exchanged, often by establishing a set of qualities deemed to be significant, including prices; and (3) Means of making calculations and exchanges, comparing and valuing the qualities of goods and services. Given this paper's focus on business-to-business marketing, the derivation of demand is vital to the extent that what might be a spillover into or from a specific market is part of a market system, with connections being organised by a conduit, a working infrastructure processing and exchanging goods and services with different technical qualities (Richardson, 1972). Table 3 (below) summarises the calculations concerning exchanges and 
investments in the infrastructure of exchanges and production processes arranged around the three domains of exchange. 
Table 3, Analysis of interests

\begin{tabular}{|c|c|c|c|}
\hline & Density of Exchanges & $\begin{array}{l}\text { Calculations and } \\
\text { Measurements }\end{array}$ & $\begin{array}{l}\text { Investments \& } \\
\text { Dependencies }\end{array}$ \\
\hline Domain 1 & $\begin{array}{l}\text { Doorstep collections } \\
\text { among households, } \\
\text { weekly or once every } \\
\text { two weeks, where } \\
\text { offered and in advance } \\
\text { of legislative } \\
\text { requirements. }\end{array}$ & $\begin{array}{l}1.5 \text { kg per household } \\
\text { per week } \\
\text { Household trade-offs } \\
\text { across conduits, } \\
\text { including emotional } \\
\text { and practical } \\
\text { significance of left- } \\
\text { overs retained within } \\
\text { household } \\
\text { The additional work in } \\
\text { sorting leftovers } \\
\text { The consequences of } \\
\text { making leftovers } \\
\text { visible - enabling 'lined } \\
\text { caddie arithmetic' }\end{array}$ & $\begin{array}{l}\text { Household } \\
\text { investments in } \\
\text { storage, including } \\
\text { refrigerators, freezers } \\
\text { and microwaves } \\
\text { Local authority } \\
\text { investments in } \\
\text { equipping households } \\
\text { with caddies and } \\
\text { liners, and in kerbside } \\
\text { collection services. } \\
\text { Investments, often } \\
\text { grant-assisted, in trials } \\
\text { and experiments in } \\
\text { food leftovers } \\
\text { collections }\end{array}$ \\
\hline Domain 2 & $\begin{array}{l}\text { Tendering and } \\
\text { contracting among } \\
\text { local authorities and } \\
\text { waste management } \\
\text { companies. }\end{array}$ & $\begin{array}{l}\text { Statutory obligation for } \\
\text { local authorities to } \\
\text { weigh waste collected } \\
\text { annually across } \\
\text { different categories, } \\
\text { including food, and } \\
\text { report the waste's } \\
\text { destination (eg., } \\
\text { composting, landfill, } \\
\text { incineration) } \\
\text { Ad hoc survey work } \\
\text { across composting } \\
\text { and AD plants, } \\
\text { recording gate fees } \\
\text { and volumes treated } \\
\text { Calorific values and } \\
\text { processing qualities of } \\
\text { biomass } \\
\text { Planning applications } \\
\text { for new waste } \\
\text { management facilities, } \\
\text { setting out annual } \\
\text { processing capacity } \\
\text { Gate-fees offset } \\
\text { against landfill } \\
\text { charges. }\end{array}$ & $\begin{array}{l}\text { Waste management } \\
\text { companies need } \\
\text { processing facilities, } \\
\text { which have different } \\
\text { pay-back profiles } \\
\text { estimated for future } \\
\text { time periods. } \\
\text { Measurements of } \\
\text { average yields per } \\
\text { household, or total } \\
\text { yields per local } \\
\text { authority area, } \\
\text { annually. } \\
\text { Assessments of gaps } \\
\text { between collections } \\
\text { through trials, and } \\
\text { measurements of } \\
\text { realised collections } \\
\text { Measurements of top- } \\
\text { up feedstocks, subject } \\
\text { to technical } \\
\text { specifications of } \\
\text { processing - waste } \\
\text { management contracts } \\
\text { with commercial and } \\
\text { public sector } \\
\text { organisations }\end{array}$ \\
\hline Domain 3 & $\begin{array}{l}\text { Multiple exchanges } \\
\text { across renewable } \\
\text { energy producers with } \\
\text { electricity and gas } \\
\text { suppliers. }\end{array}$ & $\begin{array}{l}\text { Values of Renewable } \\
\text { Heat Incentives and } \\
\text { Feed-in Tariffs } \\
\text { Standards of gas } \\
\text { quality, and reliability } \\
\text { of supply for gas and } \\
\text { electricity }\end{array}$ & $\begin{array}{l}\text { Gas scrubbing } \\
\text { equipment, grid } \\
\text { connection }\end{array}$ \\
\hline
\end{tabular}




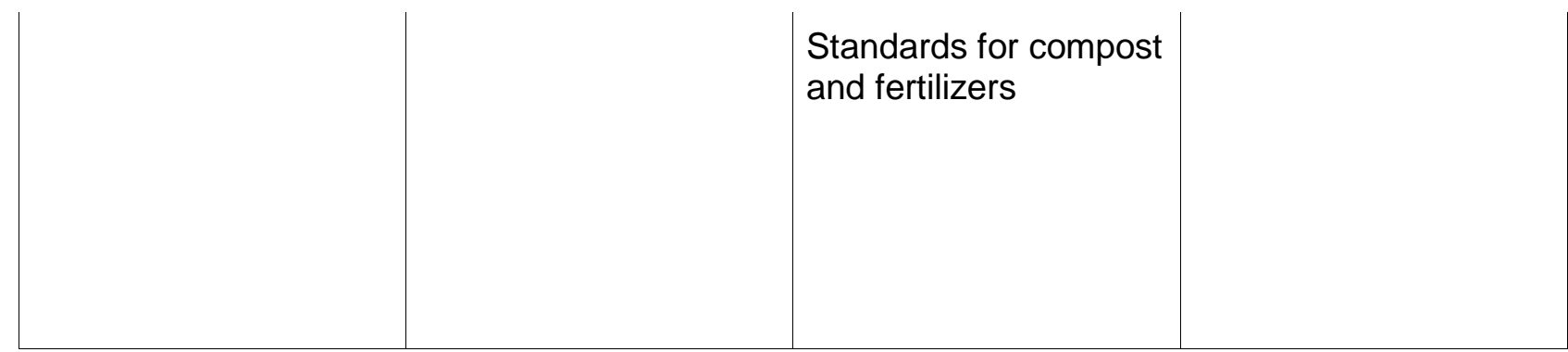

We identify three themes in Table 3 pertaining to the acquisition of data and the ability of participants to make calculations: (1) The density of exchanges, (2) The significant calculations and those making them, and (3) The market and marketing investments and connectivity across domains, which fits closely with the development of a conduit. Currently, only some local authorities undertake kerbside collections of food leftovers, although more are introducing this service in advance of the requirement of the Waste (Scotland) Regulations (2012), for household food waste to be separated from 2016. Regulators, local authorities and waste management companies circulate different data and calculations, the first being of 1.5 kilograms per household per week. This was reported across trials sponsored by WRAP (2010) and Zero Waste Scotland (2011), and has become something of a standard, being written into a performance measure by SEPA (2012). The quantity suggests that higher yields could be collected as it is calculated as an average among those households that were in an area for a trial, whether participating or not. The figure has multiple meanings, of 'shock' value for households as something that should be lower, as well as a target for collection among local authorities, and of the potential for gathering feedstock for waste management companies. However, as the operations manager pointed out in interview, 'if only the actual collected amounts could approach 1.5 kilograms per household per week'.

The second domain of exchange shifts focus to local authorities and waste management companies. Three of our interviewees - one of the business unit managers, the business development manager and the sales manager - discussed their frustrations about the inability of local authorities and other public agencies in commencing collections services, even for trial 
periods, in order that these reveal likely yields for food leftovers, especially in city locations. The crucial calculation in this domain is of 'how much', and of understanding factors that affect households' participation. The investments are by local authorities in providing households with caddies and liners and adapting their collection schedules. The benefits to local authorities are partly in preparing for compliance with legislation, saving in their uses of landfill, and with an additional benefit of placing the sorting work within households. SEPA (2014) is becoming active in this domain, in publishing data on the weight of waste collected in Scotland, presently as arising from household collections, arranged by category, by local authority area and by means of treatment (categorized as composting, incineration and landfill). SEPA (2011) instigated consultation on its measurement strategy, and it is to be extended to cover business and industry collections, made by local authorities and waste management companies. In additional, WRAP and Zero Waste Scotland undertake periodic surveys across waste management facilities, assessing volumes, capacity and gate fees. AD pant operators draw on experiments that assess the calorific value of different feedstock, to include domestic kitchen waste (WRAP, 2013; Andersons Centre, 2010). 'Wet kitchen waste', although variable in quality, has a calorific value comparable with biomass crops, yielding 140m3 of biogas per tonne in a typical industrial scale AD facility (WRAP, 2011). Finally, waste management companies are acutely aware of plans among rivals for developing new facilities, as AD or IVC. These capacities are calculated readily from documents made public through the planning process, as with SEPA (2010), and as the business development manager explained, from the usual informal information exchanges among waste management companies and local authorities.

Within this second domain, local authorities and waste management companies are developing models to assess their interests over planning periods (which tend to be shorter for local authorities, governed by regulatory and legislative compliance, and longer for waste management companies with AD facilities, governed by the pay-back periods for their investments). The models have the potential to be performative or counter-performative, and influence the extent to which investments are made in collecting and processing food leftovers. The calculations require considerable combination work, and of contending with calculations pertaining to different time 
periods, each with more or less exposure to uncertainty. Data themselves require verification, meaning that it can be a year old upon circulation, leaving waste management companies and local authorities to make inferences of it for current calculations. WRAP and Zero Waste Scotland have an interest in waste management companies investing in composting facilities, as well as in promoting reductions in the production of waste, something of which one of our interviewees, again the operations manager was keenly aware, 'We need to know is ZWS still promoting trials for commingled as well as separated waste, and what are their plans for promoting separating waste to households'.

The third domain of exchange, between waste management companies operating AD plants and the operators of the national grids in electricity and gas, was less contentious regarding its calculations than domains one and two. The concerns of the business development and procurement managers were of securing feedstock to ensure efficient plant operation, and of understanding what potentially was available and under which terms, among other sources of feedstock additional to local authorities. The primary concern was in earning gate fees in exchange for wage management services. The income stream from selling electricity was a secondary concern. Feed-in Tariffs are published over a ten-year period and were taken to be reliable. Engineering and business unit managers expressed concerns as to the technical reliability of $A D$ plants, in providing a continuous flow of processing and gas production to work close to capacity, this being subject again to the volume, flow and mix of feedstock. Despite the publication of the PAS110 standard, markets for solid and liquid fertiliser were under-developed so calculations of these did not impinge upon operational or investment decisions.

\section{Discussion of findings}

$A D$, as a means of sustainable waste management, develops, connects and sustains distinct domains of exchange. Capturing these as in-the-making indicates three kinds of contest. First, as shown Table 3, actors have different involvements and interests across the three domains. The domains provide adequate framings of interests for households and local authorities, but waste 
management companies, although not undertaking household waste collections, have an interest in understanding current volumes and trends affecting those volumes. The need for waste management companies to operate at scale, set by the size of their AD (or IVC) facilities, requires their participation in a number of commercial exchanges, contracting with local authorities, offering waste management services to business and other non-domestic organisations, commissioning and operating AD plants, and supplying electricity or methane to national power grids. Second, public agencies are acquiring a critical role in providing trustworthy data on waste volumes, whether this is through sponsoring and publishing the results of collection trials, or publishing data on collected volumes in usable formats. This is additional to creating the spaces for exchanges through legislation, of requiring businesses and households to separate food waste. Third, as the three domains of exchange identified in this section are in-the-making, so is the market system of sustainable waste management. Actors recognise that each cluster of data is incomplete, with data being dated, referring to older states of exchanges and conduit, and capable of supporting multiple interests. In this sense, the data are bound up in interests and are performative by means especially of making inferences from the results from collection trials. As some households revealed in the collection trials that they have as much as 3.5 kilograms of food leftovers per week which they set out for local authority collection, should they be reducing this, or making it available to become valuable feedstock? WRAP $(2008,2013)$ and ZWS (2011) publish findings following established social scientific standards. Nevertheless, both organisations have an interest in waste management companies installing processing capacity for sustainable waste management. Waste management companies reflect on their operational experiences, which are measured given the process of charging gate fees, taking their plants to be, in Callon's (2010) terms, experiments (or performations) of 'scale one'. The uncertainties faced by waste management companies, reflecting the scale of their operations and investments, leads them to frame the domains of exchange as a market system, through which they envisage and contribute to conduits, especially connecting household food leftovers with feedstock for AD, and derive demand across different interdependent demands.

\section{Conclusion}


We highlight the importance of conduits, or working infrastructures, in shaping markets and other domains of exchange and ordering their connectivity, such that actors may move things along, across and between markets and other domains of exchange. Given the circumstances of waste management, and of the markets and other domains of the exchange being in-the-making, the conduit, its role as a working infrastructure, is visible, contentious and important in realising policy commitments towards sustainability (variously, a low carbon economy, a circular economy, and less use of landfill and incineration as waste management facilities). As the conduit becomes visible, it draws attention to how actors use it, connect its parts together, encourage its use, encompassing an overall and multi-actor market and marketing system. We organise our conclusions by elaborating upon the paper's contributions.

(1) The sustainable management of food waste involves business-to-business marketing, especially in assessing how demand is derived across a succession of industrial processes and domains of exchange.

Following market studies research, deriving demand includes elements of exchange and of organised spillovers, in that it requires actors to cope with uncertainty, approximate calculations from arm's length, and multiple dimensions to exchanges, some commercial, some of information and some of promises, for example of other investments to come, or of a willingness to use a conduit. For example, WRAP's (2013) survey of food waste presents a simple categorisation, of unavoidable, possibly avoidable, and avoidable categories, which was promoted through press releases in media coverage. It is an example of attempting to do things with words, with marketing communications, of equipping and formatting households to move along their food left overs (Cochoy, 2008). The principle of derived demand is long established in business-to-business marketing, but little attention has been paid to the ways in which goods and services are moved along, especially as these pass through multiple markets or domains of exchange. Market studies research has provided us with explanations of how exchanges and markets are mutually constitutive, especially by means of framings and overflows. Deriving demand, especially in 
business-to-business settings requires us to pay much more attention to those overflows, to working infrastructures that support (multiple) exchanges and also attempt to sort out at least some of the framings' overflows.

(2) Some significant practices in waste management processes are performative in respect of the material and social qualities of a conduit, for example in households' participation, and waste management companies' investments in processing facilities.

The conduit is not connected tightly, not all actors have the same interests and extents of interests, and ways of coping with uncertainty. Rather, the conduit is subject to being in-the-making with investments. Examples of performativity include caddies, liners and categories for sorting food leftovers, food waste collection trials, experiments, and early-stage operational experience, all requiring that interested actors make inferences. Sustainable waste management has a market and marketing system owing to the connectivity afforded by a conduit. There are contests of data, especially as actors make inferences and envisage consequences. The implications for practitioners of viewing waste management as a conduit is in assembling and combining market knowledge. Consumers may be at least temporarily breaking free of a short form of performation, regarding their conduit passively, and considering their enrolment into sorting and setting out food leftovers. Their interests occasionally stray beyond the domain of exchange with local authorities, and in small rural and island economies, local AD plant have been installed providing visibility of a circular economy. We frame the case as involving a conduit in-the-making and so of performativity in long form. Waste management companies operating AD plants have the most extensive interests, which we show across the market system and its three domains of exchange, encountering multiple uncertainties and investing in long-lived processing facilities, the pay-back period for which exceeds waste management contracts.

The critical defining point about performativity is that an idea (a theory or model) becomes enacted and so can create its effects, as opposed to that idea being a more or less accurate representation of reality already in existence. Performativity assumes that an entity is 'in-the-making', indicating 
that those involved are acquiring agency and encountering uncertainty as they plan actions. While installing an $A D$ plant is a significant part of the performation of sustainable waste management, this is best understood as multiple and interdependent performativity. The insertion of an AD plant into a waste management process changes that overall waste management process, for instance in enabling the recovery of biogas, and potentially methane, which can be processed further as electricity or gas. In the absence of that AD plant, food leftovers can still be composted, for instance using an IVC facility, but this has a different conduit and material outcome. Absent uncertainty, and we can examine a succession of exchanges, with the conduit fading from interest and contention. Much of the data exists or can be gathered, combined and read as a representation of reality.

(3) In combination, installing and using a conduit as working infrastructure for sustainable waste management is an instance of performation, an expansive and long form of performativity. Contingently, the conduit guides the 'moving along' of food leftovers contingently, allowing these to be calculated, economised and acquire the characteristics of commodity.

The conduit's guidance is required to the extent to which food leftovers approach are both singularised as household sort these and set them out for kerbside collection, commoditised as a valuable feedstock for composting by AD or IVC. The conduit, in this case, can be described as a performation, as perlocutionary performativity. Marketers and marketing play an important role by means of the idea and practice of marketing research, as consultants. The food collection trials sponsored and reported by WRAP (2010) and Zero Waste Scotland (2011) are designed following sound social scientific and marketing research principles, and the reports are exhaustive in presenting data on yields and on communications and collections practices, such as collection vehicles used. But the logic of inference is not statistical and is not drawn on a sample standing in for a population. Rather, the trials, the marketing research, are proofs of concept, discussion of good practice locally, of local differences. The reports are as much handbooks of practice as 
epistemic proofs and the know-how presented, including the estimates of yields, are reliable knowledge on the basis of proof of concept.

We suggest that future research can track the developments of instances in sustainable waste management. Focusing on a case study and reflecting that the conduit, and the market and marketing system are at an early stage of being in-the-making limit the generality of this paper. One dimension worthy of further research is in whether households, along with food producers and retailers, will develop an interest beyond their current domains of exchange. Smaller-scale and local $A D$ plants have been devised in rural and island communities, perhaps enhancing a sense that households can become stakeholders in sustainable waste management and in renewable energy production. This systemic quality leads us to understand a conduit-in-the making as an instance of performativity in the long form, which Callon $(2007,2010)$ terms a 'performation' and Butler $(1997,2010)$ terms 'perlocutionary performativity'. Surplus and excess are helpful guides to the discussion, although an examination of sustainable waste management as a performation draws our attention to surplus in-the-making, or at least recovering. Evans (2012a) and Cappellini and Parsons (2013) argue that food leftovers are valued socially within and between households, and that households also use technologies including fridges, freezers and microwaves to postpone and realise these personal and social values. But as households receive requests to place their food leftovers in lined caddies, for weekly or fortnightly collection, economic valuation and calculation are prominent at least for local authorities and waste management companies as food leftovers are combined and rendered as commodity for processing at large scale. While not marketisation, this is an instance of commoditisation and calculation in an area subject to being governed by other logics. 


\section{Acknowledgements}

An earlier version of this paper was presented at the Ambiguous Goods Seminar, part of the series on Doing and Theorising Marketing Work, March 2012 in London. We are grateful to Liz Parsons and Janice Denegri-Knott for comments and criticisms. We thank Katy Mason, Johan Hagberg and Hans Kjellberg for their editorial guidance and advice, and the anonymous reviewers for their comments and criticisms. 


\section{References}

Ahi, P. and Searcy, C. 2013 A comparative literature analysis of definitions for green and sustainable supply chain management, Journal of Cleaner Production, 52, 329-341, doi: 10.1016/j.jclepro.2013.02.018

Andersons Centre 2010 A Detailed Assessment of Anaerobic Digestion Technology and its Suitability to UK Farming and Waste Systems, second edition, the Andersons Centre (with DECC and NNFCC), Melton Mowbray.

Appadurai A.1986 Introduction: Commodities and the politics of value, in Appadurai, A. (ed.) The Social Life of Things: Commodities in Cultural Perspective, Cambridge University Press, Cambridge, pp. 3-63.

Araujo, L., Finch, J.H. and Kjellberg, H. 2010 Reconnecting marketing to markets: An introduction, in Araujo, L., Finch, J.H. and Kjellberg, H., eds, Reconnecting Marketing to Markets, Oxford University Press, Oxford, pp. 1-12.

Araujo, L. and Kjellberg, H. 2009 Shaping exchanges, performing markets: The study of marketing practices, in MacLaren, P., Saren, M., Stern, B. and Tadajewski, M. (eds) The Sage Handbook of Marketing Theory, Sage, London, pp. 195-217.

Austin, J.L. 1962 How to do Things with Words, Harvard University Press, Cambridge, MA.

Barratt, M., Choi, T.Y. and Li, M. 2011 Qualitative case studies in operations management: Trends, research outcomes and future research implications, Journal of Operations Management, 29(3), 329-342, doi: 10.1016/j.jom.2010.06.002

Belk, R.W. 1987 ACR presidential address: Happy thought, Advances in Consumer Research, 14, 1-4.

Beunza, D. and Stark, D. 2004 Tools of the trade: The socio-technology of arbitrage in a Wall Street trading room, Industrial and Corporate Change, 13(2), 369-400, doi: 10.1093/icc/dth015

Bowker, J. and Star, S.L. 1999 Sorting Things Out: Classification and its Consequences, MIT Press, Cambridge AM.

BSI 2010 PAS110:2010, British Standards Institute (with WRAP), London.

BSI 2011 PAS 100:2011 (third edition), British Standards Institute (with WRAP), London.

Bulkeley, H. and Gregson, N. 2009 Crossing the threshold: Municipal waste policy and household waste generation, Environment and Planning A, 41(4), 429-445, doi:10.1068/a40261.

Bulkeley, H., Watson, M. and Hudson, R. 2007 Modes of governing municipal waste, Environment and Planning A, 39 (11), 2733-2753, doi: 10.1068/a38269.

Butler, J. 1990 Gender Trouble: Feminism and the Subversion of Identity, Routledge, New York.

Butler, J. 1997 Excitable Speech: A Politics of the Performative, Routledge, New York and London.

Butler, J. 2010 Performative agency, Journal of Cultural Economy, 3(2), 147-161, doi: 10.1080/17530350.2010.494117.

Cabantous, L. and Gond, J-P. 2011 Rational decision as performative praxis: Explaining rationality's éternal retour, Organization Science, 22(3), 573-586, doi.org/10.1287/orsc.1100.0534. 
Çalișkan, K. and Callon, M 2009 Economization part I: Shifting attention from the economy towards processes of economization, Economy and Society, 38(3), 369-398, doi:

10.1080/03085140903020580

Çalișkan, K. and Callon, M 2010 Economization part II: A research programme for the study of markets, Economy and Society, 39(1), 1-32, doi: 10.1080/03085140903424519.

Callon, M. 1998a Introduction: the embeddedness of economic markets in economics, in Callon, M. (ed) The Laws of the Markets, Blackwell Publishers and the Sociological Review, Oxford, pp. 157.

Callon, M.1998b An essay on framing and overflowing: Economic externalities revisited by sociology, in Callon, M. (ed) The Laws of the Markets, Blackwell Publishers and the Sociological Review, Oxford, pp. 244-269.

Callon, M. 2007 What does it mean to say that economics is performative? In MacKenzie, D., Muniesa, F. and Siu, L. (eds) Do Economists Make Markets? On the Performativity of Economics, Princeton University Press, Princeton NJ., pp. 311-357.

Callon, M. 2009 Civilizing markets: Carbon trading between in vitro and in vivo experiments. Accounting, Organizations and Society, 34, 3-4, 535-548, doi: 10.1016/j.aos.2008.04.003.

Callon, M. 2010 Performativity, misfires and politics, Journal of Cultural Economy, 3(2), 163-169, doi: $10.1080 / 17530350.2010 .494119$

Callon, M., Méadel, C. and Rabeharisoa, V. 2002 The economy of qualities, Economy and Society, 31(2), 17-46, doi: 10.1080/03085140220123126.

Callon, M and Muniesa, F. 2005 Economic markets as calculative collective devices, Organization Studies, 26(8), 1229-1250, doi: 10.1177/0170840605056393.

Cappellini, B. 2009 The sacrifice of re-use: The travels of leftovers and family relations, Journal of Consumer Behaviour, 8(6), 365-365, doi: 10.1002/cb.299.

Cappellini, B. and Parsons, E. 2013 Practising thrift at dinnertime: Mealtime leftovers, sacrifice and family membership, Sociological Review, 60, 117-130, doi: 10.1111/1467-954X.12041.

Cochoy, F 2008 Calculation, qualculation, calqulation: Shopping cart arithmetic, equipped cognition and the clustered consumer, Marketing Theory, 8(1), 15-44, doi: 10.1177/1470593107086483

Cochoy, F. 2010 Reconnecting marketing to 'market-things': How grocery equipment drove modern consumption (Progressive Grocer, 1929-1959), in Araujo, L., Finch, J.H. and Kjellberg, H. (eds) Reconnecting Marketing to Markets, Oxford University Press, Oxford, pp. 29-49.

Czarniawska B. 2004 On time, space and action nets, Organization, 11(6), 773-791, doi: 10.1177/1350508404047251.

D'Adderio, L. and Pollock, N. 20142014 Performing modularity: Competing rules, performative struggles and the effect of organizational theories on the organization, Organization Studies, online in advance of publication, doi: 10.1177/0170840614538962

DECC 2009 Biomethane into the Gas Network: A Guide to Producers, Department of Energy and Climate Change, London.

DECC 2011 Renewable Heat Incentive, Department of Energy and Climate Change, London. 
DEFRA 2011 Anaerobic Digestion Strategy and Action Plan, Department of Environment and Rural Affairs with Department of Energy and Climate Change, London.

DEFRA 2012 Optimising Inputs and Outputs from Anaerobic Digestion Processes, Final Research Report WR0212, Department for the Environment and Rural Affairs, London.

Doganova, L. and Eyquem-Renault, M. 2009 What do business models do? Innovation devices in technological entrepreneurship, Research Policy 38(10), 1559-1557, doi:

10.1016/j.respol.2009.08.002.

Doganova, L. and Karnoe, P. forthcoming a, Clean and profitable: Entangling valuations in environmental entrepreneurship, in Anatal, A.B., Hutter, M. and Stark, D. (eds) Moments of Valuation: Exploring Sites of Dissonance, Oxford, Oxford University Press.

Doganova, L. and Karnoe, P. forthcoming b, Building markets for clean technologies:

controversies, environmental concerns and economic worth, Industrial Marketing Management.

Evans, D. 2011 Blaming the consumer - once again: The social and material contexts of everyday food waste in some English households, Critical Public Health, 21(4), 429-440, doi: 10.1080/09581596.2011.608797.

Evans, D. 2012a Binning, gifting and recovery: The conduits of disposal in household food consumption, Environment and Planning D: Society and Space, 30, 1123-1137, doi:10.1068/d22210.

Evans 2012b Beyond the throwaway society: Ordinary domestic practice and a sociological approach to household waste, Sociology, 46(1), 41-56, doi: 10.1177/0038038511416150.

Finch, J.H. and Geiger, S. 2010 Positioning and relating: Market boundaries and the slippery identity of the marketing object, Marketing Theory, 10(3), 237-252, doi:

$10.1177 / 1470593110373188$

Finch, J.H. and Geiger, S. 2011 Constructing and contesting markets through the market object, Industrial Marketing Management, 40(6), 899-906, doi: 10.1016/j.indmarman.2011.06.034

Gregson, N. Metcalfe, A. and Crewe, L. 2007a Moving things along: The conduits and practices of divestment in consumption, Transactions of the Institute of British Geographers, NS 32(2), 187200, doi: 10.1111/j.1475-5661.2007.00253.x.

Gregson, N. Metcalfe, A. and Crewe, L. 2007b Identity, mobility and the throwaway society, Environment and Planning D: Society and Space, 25(4), 682-700, doi: 10.1068/d418t.

Gregson, N., Watkins, H. and Calestani, M. 2013 Political markets: Recycling, economization and marketization, Economy and Society, 42(1), 1-25, doi: 10.1080/03085147.2012.661625.

Hines, P. 1993 Integrated materials management: The value chain redefined, International Journal of Logistics Management, 4(1), 13-22, doi: org/10.1108/09574099310804920.

Ingold, T. 2007 Materials against materiality, Archeological Dialogues, 14(1), 1-16, Tim Ingold (2007). Materials against materiality. Archaeological Dialogues, 14, pp 1-16. doi: 10.1017/S1380203807002127..

Kjellberg, H. and Helgesson, C-F. 2006 Multiple versions of marketing: Multiplicity and performativity in market practice, Industrial Marketing Management, 35(7): 839-855, doi: 10.1016/j.indmarman.2006.05.011. 
Kjellberg, H. and Helgesson, C-F. 2010 Political marketing, Journal of Cultural Economy, 3(2), 279297, doi: 10.1080/17530350.2010.494379.

Kopytoff, I.1986 The cultural biography of things: Commoditization as process, in Appadurai, A. (ed) The Social Life of Things: Commodities in Cultural Perspective, Cambridge University Press, Cambridge, pp. 64-91.

Latour, B. 1987 Science in Action. How to Follow Scientists and Engineers through Society, Harvard University Press, Cambridge, Massachusetts.

Latour, B. 2005 Re-assembling the Social: An Introduction to Actor-Network-Theory, Oxford University Press, Oxford.

Law, J. 2004 After Method: Mess in Social Science Research, Routledge, London and New York.

Goulding, T. 2014 Scotland sees surge in food waste treatment, Let's Recycle, June, available at: http://www.letsrecycle.com/news/latest-news/compost/scotland-sees-surge-in-food-wastetreatment (accessed 8th September 2014).

MacKenzie, D. 2006 An Engine, Not a Camera: How Financial Models Shape Markets, MIT Press, Cambridge, MA.

MacKenzie, D. 2009 Making things the same: Gases, emission rights and the politics of carbon markets, Accounting, Organizations and Society, 34, 3-4, 440-455, doi: 10.1016/j.aos.2008.02.004.

MacKenzie, D. and Millo, Y. 2003 Constructing a market, performing a theory: The historical sociology of a financial derivatives exchange, American Journal of Sociology, 109(1), 107-145, doi: 10.1086/374404.

Mason, K.J. and Spring, M. 2011 The sites and practices of business models, Industrial Marketing Management, 40(6), 1032-1041, doi: 10.1016/j.indmarman.2011.06.032 .

Mattsson, L-G. and Johanson, J. 2006 Discovering market networks, European Journal of Marketing, 40(3/4), 259-274, doi: 10.1108/03090560610648048.

Mol, A. 2002 The Body Multiple: Ontology in Medical Practice, Duke University Press, Durham and London.

MIller, P. and O'Leary, T. 2007 Mediating instruments and making markets: Capital budgeting, science and the economy, Accounting, Organizations and Society, 32(7-8), 701-734, doi: 10.1016/j.aos.2007.02.003.

Office of Fair Trading 2011 Organic Waste: An OFT Market Study, OFT1372, Office of Fair Trading, London.

Pan, S.L. and Tan, B. 2011 Demystifying case research: A structured-pragmatic-situational (SPS) approach to conducting case studies, Information and Organization, 21(1), 167-176, doi: 10.1016/j.infoandorg.2011.07.001.

Pickering, A. 1995 The Mangle of Practice: Time, Agency and Science, University of Chicago Press, Chicago and London.

Pollock, N. and Williams, R. 2010 The business of expectations: How promissory organizations shape technology and innovation, Social Studies of Science, 40(4), 525-548, doi:

10.1177/0306312710362275. 
Richardson, G.B. 1960 Information and Investment: A Study in the Working of the Competitive Economy, Clarendon Press, Oxford.

Seuring, S. and Müller, M. 2008 From a literature review to a conceptual framework for sustainable supply chain management, Journal of Cleaner Production, 16(15), 1699-1710, doi:

10.1016/j.jclepro.2008.04.020.

SEPA 2010 Zebec Biogas Limited: Barkip Anaerobic Digestion Plant, by Beith, Ayrshire. Decision Document (Main Assessment \& PDD), form number iPPC-DD-02, Scottish Environmental Protection Agency, Stirling.

SEPA 2011 Consultation on a Waste Data Strategy for Scotland, Scottish Environmental Protection Agency, Stirling.

SEPA 2014 Scottish Waste Data Interrogator, available at:

http://www.environment.scotland.gov.uk/get-interactive/data/household-waste/ (accessed $8^{\text {th }}$ September 2014)

Shove, E. and Araujo, L 2010 Consumption, materiality and markets, in Araujo, L., Finch, J. and Kjellberg, H. (eds) Reconnecting Marketing to Markets, Oxford University Press, Oxford, pp. 13-28.

Strasser, M. 1999 Waste and Want: A Social History of Trash, Metropolitan Books, New York.

WRAP 2008 The Food We Waste, WRAP, Banbury.

WRAP 2010 Performance Analysis of Mixed Food and Garden Waste Collection Schemes, WRAP, Banbury

WRAP 2011 AD Workshop - Optimising Processes for the Stable Digestion of Food Waste, Powerpoint presentation from workshop, Bristol, $11^{\text {th }}$ January.

WRAP 2012 Anaerobic Digestion Infrastructure in the UK: September 2011, WRAP and NNFCC, Banbury.

WRAP 2013 Household Food and Drink Waste in the United Kingdom 2012, WRAP, Banbury.

Zero Waste Scotland 2010 Scottish Food Waste Collection Trial: Performance and Evaluation, Zero Waste Scotland, Edinburgh

Zero Waste Scotland 2012 Local Authority Kerbside Good Practice Guide: Kerbside Waste and Recycling Collections, Zero Waste Scotland, Edinburgh. 